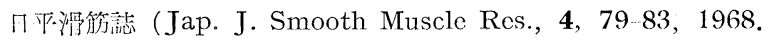

\title{
食道外瘦法電気内压曲線
}

\author{
千葉大学垁学部 佐藤外科教空 \\ (主任 位藤 博教授) \\ 佐藤 博, 平息 毅, 西村朋, 嫶田彭邱, 佐々木等 \\ 黄 江庭, 金城和夫, 原 輝䖉, 大山修身, 三好弘文 \\ 竹島 徹
}

\section{A STUDY OF RESTING AND DEGLUTITION PRESSURES IN THE ESOPHAGUS AND THE GASTROESOPHAGEAL JUNCTION WITH CERVICAL ESOPHAGOSTOMY}

\author{
Hiroshi Sato, Tsuyoshi Hirashima, Akira Nishimura, Akio Shiota, \\ Mamoru Sasaki, Kotei KoH, Kazuo Kinso, Teruhiko Hara, Osami \\ Ohyama, Hirohumi Mryoshi, Tohru Takeshima
}

The Second Department of Surgery, School of Medicine, Chiba University, Chiba

(Director: Prof.H.Sato)

\begin{abstract}
The pressures in the esophagus and gastro-esophageal sphincter in 22 healthy unanesthetized dogs were studied by the use of three small open tipped tubes with internal diameter of $1.4 \mathrm{~mm}$. The tubes were introduced and manipulated without anesthesia through the previously made esophageal fistula. To record the resting pressure, an open tipped tube was withdrawn slowly from the stomach back to the esophagus. The swallowing action was induced by an injection of water into the esophagus.

The resting pressure in the esophagus was less than that in the fundus of the stomach. A band of elevated pressure was recorded at the gastro-esophageal junctional area in the dogs while at rest. The mean maximal pressure in this area was $9.5 \mathrm{~cm} \mathrm{H}_{2} \mathrm{O}$ and the mean width was $2.6 \mathrm{cmH}_{2} \mathrm{O}$.

As for the changes in pressure during swallowing, the peristaltic waves were seen to sweep downward in the esophagus. In the gastro-esophageal junctional area, the negative wave (relaxation) occurred 4 seconds after the onset of water injection inducing swallowing, lasting about 3 seconds, and was followed by the positive wave (contraction) lasting 3.3 seconds.
\end{abstract}

緒

正常食道運動特に食道胃接合部の動態については古く から多くの人により研究されているが，まだ未解決の問 題が少なくない。また食道の機能的疾患の一つである特 発性食道拡張症の成因および病態の究明, さには術式の 検討などのため動物を用いて各種の実験が試みられるよ うになって来たが，乙れらの研究に食道電気内圧曲線検 查は欠くととのできない検査法の一つである.しかし，イ

\section{実験 方 法}

\section{1. 食道外掼作製}

体重 $10 \mathrm{~kg}$ 前後の雑種成犬 22 頭を用い，24 時間絶

\section{言}

又を無麻酔無拘束の生理的状態で内圧測定を行なうこと は非常に困難で,そのような報告は本邦には見当らず, 欧 米においてもそれ程多くない。そてでわれわれは Harri ${ }^{\mathrm{S}}$

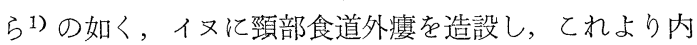
圧誘導管を挿入し，無麻酔無拘束の状態で内圧測定を行 なった．今回は正常なイヌの食道静止圧および噮下に伴 なう内圧変化について若干の知見を得たので報告する。

食後, ネンブタール静脈麻酔下に Ware \& Howe $\mathrm{e}^{2)}$ の方 法にしたがって食道外瘦造設術を行なった。すすおち左。 
頸部で 喉頭と胸骨上縁の中央で胸鎖乳突筋と下舌骨筋 の間より頸部食道に至り，てれを周囲から剶離し持ち上 げ，迷走神経を傷つけることなく食道を并状に切開し， 皮膚に固定し外瘦とする。

\section{2. 食道内圧測定}

食道外瘦造設後 3 日以上を経て一般状態が回復してか ら行なった. 24 時間絶食とし，何ら前処置を行なわず 無麻酔無拘束のもとに, 食道外棲より内径 $1.4 \mathrm{~mm} の 1$ 本のポリエチレン管を胃まで捕入し，徐々に引きながら 静止圧を測定した。ついで $3 \mathrm{~cm}$ づつ先端のずれた 3 本 のチューブとさらに $5 \mathrm{~cm}$ 上方に先端の開口する水注入 用チューブ計 4 本を一束とした内圧誘導管で, 冷水 $5 \mathrm{ml}$ 注入により罯下運動をおこさせ内圧変化を測定した。す ベてオープンキップ法で行ない，日本光電工業製多用途

\section{実}

\section{1. 食道静止圧}

静止圧は胃内呼気終圧を基準にとりゼロとした。静止 圧曲線の 1 例在図 2 亿示す。上は内圧誘導管を 10 秒間 に $1 \mathrm{~cm}$ の速さで引き抜きながら同速度で移動する記録 紙に描記したもので，下は記録紙の速さのみ 10 倍にし たものである．胃内圧は呼吸の影響により下方に凸の曲 線の連続として出現し，その最下点が呼気終圧を示しほ とんど一定しており，最高点は吸気終圧である。吸気終 圧は 22 頭平均 $3.2 \mathrm{~cm} \mathrm{H}_{2} \mathrm{O}$ であった。チューブを胃内 より食道へと徐々に引き抜くと，いわ的る下部昇圧带を 形成し, その間で呼気終圧と吸気終圧は逆転し上方に凸 の食道静止压の波型に変わる。昇圧带の呼氛終圧か段々 下降し, 食道の静止圧として安定する境界を下部昇圧带 の食道側境界々定めた。胃側境界は呼気終圧が基線を離 れて上昇し始める点とした。図 2 下に示すように下部昇 圧带は胃呼気終圧をゼロとするので，陽圧部分(陽性部)

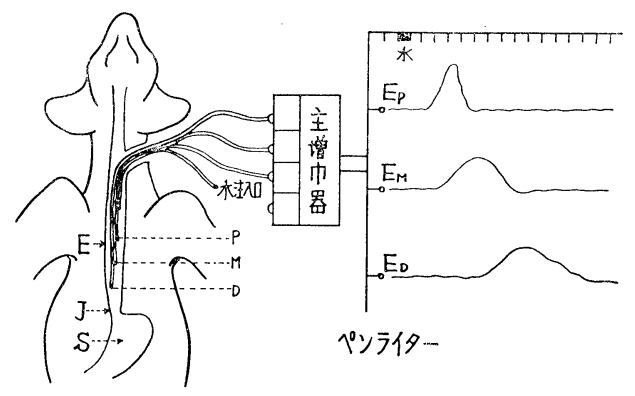

図 1. 食道外瘦による内圧誘導法（イヌ）

監視記録製置を用いペン書きオシログラフにて記録した (図 1). 測定の実際についてはわれわれの教室における 詳しい報告3)があるので省略した。

\section{成 績}

と陰圧部分（陰性部）とに分けられ，さらに呼吸相変換 点により生理的横隔膜附着部上部々下部に分けられる.

てれら諸点の長さおよび静止圧平均值は図 3 亿示す如く であった。 22 頭中，下部沓圧帯の出現しなかったもの は 1 頭もなく, 最高圧はいづれも呼吸相変換点より食道 側に存在した。 下部昇圧帯の長さは平均 $2.6 \mathrm{~cm}$ で陽性 部は $1.9 \mathrm{~cm}$ であった。食道静止圧は上，中，下部とも に陰圧を示した。下部食道では呼気終圧 $-8.4 \mathrm{~cm} \mathrm{H}_{2} \mathrm{O}$, 吸気終圧 $-15.3 \mathrm{~cm} \mathrm{H}_{2} \mathrm{O}$ であった。中部食道では -9.0 $\mathrm{cm} \mathrm{H}_{2} \mathrm{O}$ および $-15.2 \mathrm{~cm} \mathrm{H} \mathrm{H}_{2} \mathrm{O}$, 上部食道で $-7.5 \mathrm{~cm}$ $\mathrm{H}_{2} \mathrm{O}$ およびー $13.4 \mathrm{~cm} \mathrm{H}_{2} \mathrm{O}$ であった。すなわち中部食道 で最も陰圧を示し，呼吸の影響は下部食道へいく程大き い傾向を示した。なおててで上，中，下部食道とは下瘦 より下部昇圧帯食道側境界を 3 等分りてて規定した。

\section{2. 食道内圧変化}

22 頭中内圧変化測定不能 2 頭を除き 20 頭につき検

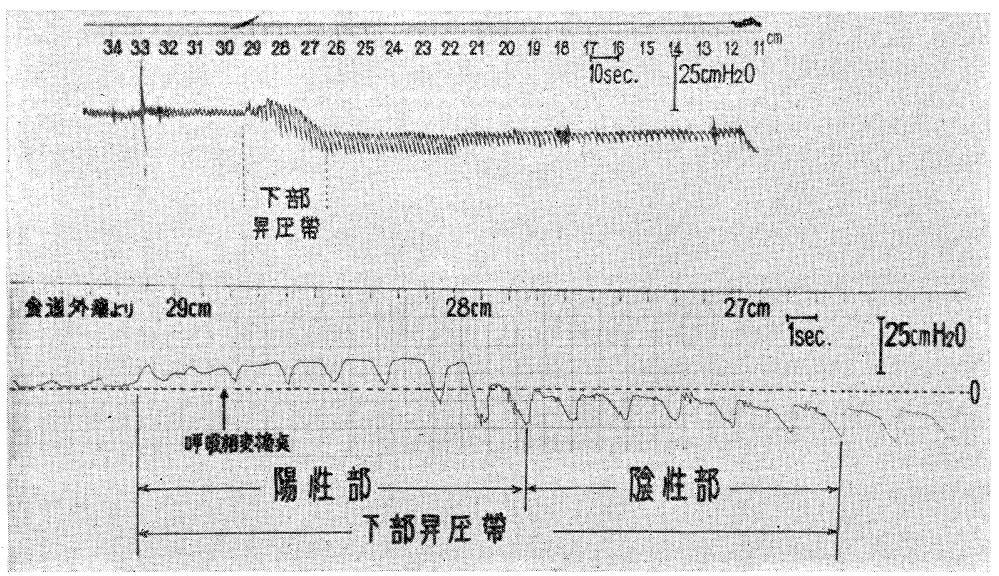

図 2 , 食道静止圧曲線 正常イ又 


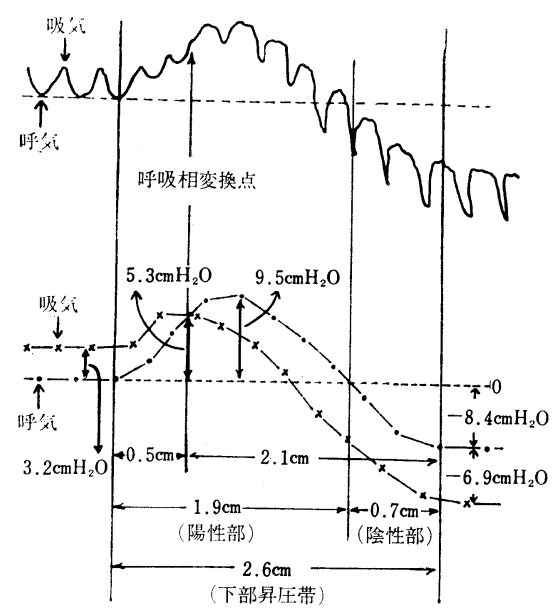

図 3 . 食道胃接合部静止圧部位別平均值

討した。図 1 に示すように，水注入口より冷水 $5 \mathrm{cc}$ を注 入すると一定の発現時間をもって上, 中, 下部食道へと 陽性波が出現した。図 4 は内圧変化の 1 例である.上より 上部, 中部, 下部食道, および下部昇圧帯に相当する食道 胃接合部での内圧変化で,てのように接合部においては, 陰性波とこれに続く陽性波の 2 相性の波型を示した。さ らに胃内では陽性波は認められなかった。冷水注入開始 より陽性波の立ち上るまでの時間を発現時間とし，陽性 波の立ち上りより基線へ戻るまでの時間を持続時間とし た。発現時間は上部食道より下部へいく程延長を示し た. 図 5 の如く平均值は上部食道 2.6 秒，中部食道 3.2 秒，下部食道 4.4 秒で，接合部では 3.9 秒で陰性波が発 現し，2.6 秒持続するので，陽性波は 6.5 秒して発現し たととになる．陽性波の持続時間は，上部食道 0.5 秒， 中部食道 1.5 秒, 下部食道 2.8 秒と下方にいくにした
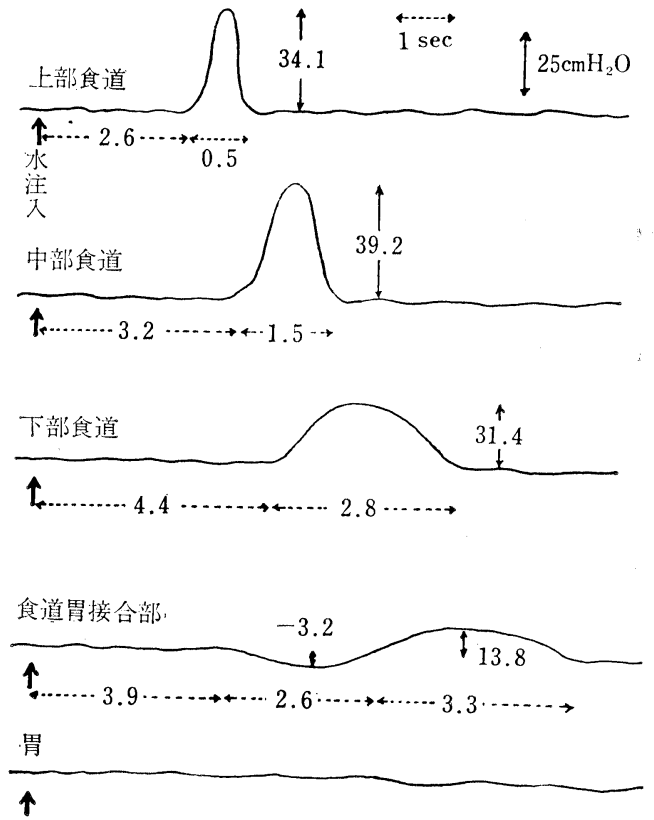

図 5. 内圧変化部位別平均值

って延長し，接合部では 3.3 秒であった．陽性波の最高 值は中部食道で最高を示し $39.2 \mathrm{~cm} \mathrm{H}_{2} \mathrm{O}$ で, 上部食道 $34.1 \mathrm{~cm} \mathrm{H} \mathrm{H}_{2} \mathrm{O}$ ，下部食道 $31.4 \mathrm{~cm} \mathrm{H}_{2} \mathrm{O}$ ，であった，接合 部では陰性波高 $-3.2 \mathrm{~cm} \mathrm{H}_{2} \mathrm{O}$ で陽性波高は $13.8 \mathrm{~cm}$ $\mathrm{H}_{2} \mathrm{O}$ であった。 なお 20 頭中, 陰性波の発現を認め難い ものが 5 頭あった。 また冷水注入で毎回陽性波が発現す るわけでなく, 同一犬においても水注入回数が多くなる 程, 発現時間が多少延長する傾向にあり, 陽性波欠如の 頻度夫增す傾向が認められた。

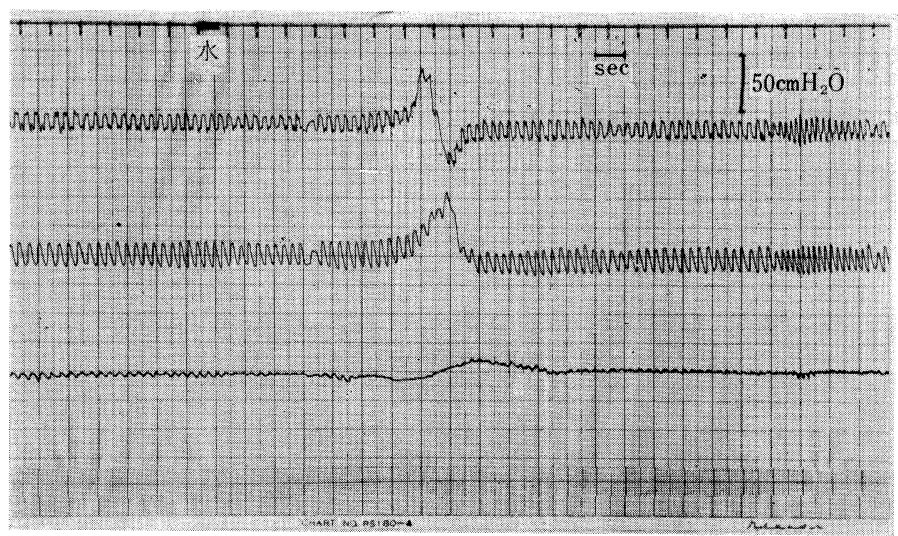

図 4. 食道・接合部の内圧変化（食道外瘻法） 


\section{考}

イヌを無麻酔の状態で食道内圧検査を行なうことは非 常に困難である. Greenwood らさお および Schlcgel \& Code ${ }^{5)}$ らもイヌを充分馴らしてチューブを口より挿入 し，無麻酔での食道内圧測定に苦労している，本邦にお いてはてのような報告は見当らず, 坂西( ${ }^{(3)}$, 水野7), 佐 藤8,9) らはイヌの食道内圧測定に当って共に Ravonal ま たは Nembutal で全身麻酔を施行している.しかし Harris ら1) はイヌで DFP による特発性食道执張症様 動物作製実験の際, 頸部食道外瘦より内圧測定を行なっ ている. 本法によればチューブ飲み込みの訓練は全く不 要であり，検查中にチューブが口腔，咽頭るどを刺激し ないのでイヌは嘔吐運動, 体動をおてさない. 欠点とし ては咽頭食道移行部, すなわち上部昇圧帯の内压測定が 不可能なととである，ともあれ本法を行なえば，無麻酔 無拘束の最も生理的な状態で, イヌを始め各種実験動物 の食道電気内圧測定が可能である.

イヌの食道運動を内圧曲線より詳細に検討を加えた報 告は欧米には比較的多いが，本邦には殆ど見当らない. 先づ静止圧であるが，圧基準をどとにとるかは議論のあ る処であるが，イヌでは胃静止圧，それも呼気終圧をゼ ロとするのが便利と思われる。ヒトの下部昇圧帯につい てはFyke ら ${ }^{10)}$ の詳細な研究, Muller ${ }^{11)}$, Kelley ${ }^{12)}$ の報 告など枚挙にいとまがないが，イヌにおいては, Schlegel \& $\operatorname{Code}^{5)}$ が 7 頭の正帯犬について，下部昇圧帯の長さ $2.5 \mathrm{~cm}$, 最高圧 $9 \mathrm{~cm} \mathrm{H}_{2} \mathrm{O}$ と報告している. 彼らはさら に 19 人の健康人の下部昇圧帯と比較してその長さはや や短いが，最高圧では大差がないと述べている。 Williams $^{13)}$ は 6 頭の正常犬で胃呼気終圧をゼロとして， 胃内圧 $1.2 \mathrm{~cm} \mathrm{H}_{2} \mathrm{O}$, 下部昇圧帯最高圧 $25.1 \mathrm{~cm} \mathrm{H}_{2} \mathrm{O}$, 長 さでは生理的横隔膜下部 $3.5 \mathrm{~cm}$, 上部 $0.35 \mathrm{~cm}$, 全長

\section{結}

正常犬 22 頭を用い食道外瘦法により食道内圧測定を 行ない次の結論を得た。

1. 食道および接合部の静止圧を測定すると, 下部昇 圧带が存在し、長さ平均 $2.6 \mathrm{~cm}$, 最高圧 $9.5 \mathrm{~cm} \mathrm{H} \mathrm{H}_{2} \mathrm{O}$ で あった。下部昇圧帯を陽性部と陰性部と陰性部とに区分 するととを提唱し，前者は $1.9 \mathrm{~cm}$, 後者は $0.7 \mathrm{~cm}$ であ った。

2。食道の静止圧は呼気終圧で上部食道 $-7.5 \mathrm{cmH}_{2} \mathrm{O}$ 中部食道 $-9.0 \mathrm{~cm} \mathrm{H}_{2} \mathrm{O}$, 下部食道 $-8.4 \mathrm{cmH}_{2} \mathrm{O}$ であっ t。

\section{文}

1) Harris, L.D., Ashworth, W.D. \& Ingelfinger, F.J.: Esophageal aperistalsis and
按

$3.85 \mathrm{~cm}$ としている.ただし,てれは small balloon 法に よるものである. 内圧の絶対圧, 微細な長さの検討には small balloonといえども不適当と思われる。とれらの 報告は静止圧基準線より正の部の長さ在昇圧带長として いる．昇圧帯の圧が徐々に下降して食道静止圧として安 定するまでの約 $0.7 \mathrm{~cm}$ の長さについては検討していな い. 観点を食道側におけば当然この部分も昇圧帯に含ま れるべき性質のものと解される，最高圧はオープンチッ プ法の諸家の報告とほぼ一致している．呼吸相変換点は ヒトでは昇圧帯のほば中央に位するが12)，イヌではやや 胃側に位する。食道静止圧は陰圧を呈し，Williams ${ }^{13)}$ は 吸気終圧 $-3.9 \mathrm{~cm} \mathrm{H}_{2} \mathrm{O}$, 呼気終圧 $-2.4 \mathrm{~cm} \mathrm{H}_{2} \mathrm{O}$ と述 ベている。

内圧変化で問題となるのは，噮下運動の始めより各部 位で生じる蠕動波発現までの時間測定で, Schlegel ら5) は正確を得るために喉頭筋に筋電図電極を刺入し, 口腔 への泠水注入で噮下運動を誘発し, 内圧曲線と筋電困を 同時記録している．われわれは便宜的に冷水注入から陽 性波発現までを発現時間とした，彼ららりよれば上部食 道 1.5 秒, 中食部道 3.1 秒, 下部食道 4.6 秒, 接合部 12.8 秒であり，陽性波高は各々 $36,52 ， 57,51 \mathrm{~cm} \mathrm{H}_{2} \mathrm{O}$ と報告している。また接合部陰性波については 4.6 秒し て $-16 \mathrm{~cm} \mathrm{H}_{2} \mathrm{O}$ の波高の陰性波が先行すると述べてい る. この接合部の陰性波, 陽性波 2 相性の波型は Schlegel \& Cade $^{5)}$ が述べているように食道より胃への食物輸 送機構の内圧的現われと見るととができる。すなわち， 嚥下に続いて起こる陰性波は, 噴門部の弛緩を意味し, 続く陽性波は収縮に相当する。この一連の弛緩収縮運動 により食物は胃内に転送され, 同部静止圧の高圧のた め，食道への逆流は妨げられている.

\section{語}

3. 食道内圧変化において発現時間は上部より下部へ 順次延長を示し，陽性波高は下部食道で最高で $39.2 \mathrm{~cm}$ $\mathrm{H}_{2} \mathrm{O}$ ，持続時間は下部食道へゆく程延長した。

4. 食道胃接合部では德下より約 4 秒して $-3.2 \mathrm{~cm}$ $\mathrm{H}_{2} \mathrm{O}$ の陰性波が 2.6 秒持続し， 3.3 秒持続する $13.8 \mathrm{~cm}$ $\mathrm{H}_{2} \mathrm{O}$ の陽性波に移行した。

本研究の一部は昭和 42 年度科学研究費補助金によって 行なわれた。

\section{献}

achalasia produced in dogs by prolonged cholinestelase inhibition. J. Clin. Invest., 
39, 1774-1751, 1960.

2) Ware, P.F. \& Howe C.W.: Experimental esophageal and pharyngeal fistula. A.M.A. Arch. Surg. 63, 229-233, 1951.

3) 平島 毅, 塩田彰郎, 貞永嘉久: 食道噴門部電気 内圧曲線榆査法. 胸部外科， 19，6，398-404， 1965.

4) Greenwood, R.K. et al.: Pressure and potential difference characteristics of surgically created canine hiatal hernia. Gastroenterology, 48, 602-611, 1965.

5) Schlegel, J.F. \& Code, C.F.: Pressure characteristics of the esophagus and its sphincters in dogs. Amer. J. Physiol., 193, 9-14, 1958.

6) 坂西昭夫：食道運動に関する研究補遺, 第 3 編, 食道壁下部の Auerbach's Plexus の変性に関す る実験的研究. 日胸外会誌，11，933-939, 1963.

7) 水野秀一：犬に於ける正常及び頸部迷走神経切断 時の下部食道ならびに胃噴門部の電気生理学的研 究. 日大医学雑誌，23，1-13，1964.

8) Sato, H. et al.: Studies on the spontanous cardiospasmus with special reference to its central mechanism. Nihon Univ. J. Med., 7, 85-107, 1965.

9) 佐藤 博: 特発性食道拡張症の基礎と臨㕅. 日消 誌，59，779-787，1962.

10) Fyke, F.E. \& Code, C.F.: Resting and deglutition pressure in the pharyngoesophageal region. Gastroenterology, 29, 24-34, 1955.

11) Muller, B.G.S., Astley, R. \& Carré,I. J.: A combined cineradiographic and manometric study of gastroesophageal junction. Lancet, 272, 659-664, 1957.

12) Kelley, M.L. et al.: Deglutitive responses in the gastroesophageal sphincter of healthy buman heings. J. Appl. Physiol., 15, 483-488, 1960.

13) Williams, G.S. \& Ingram. P.R.: A comparative intraluminal oncometric study of the experimentally reconstructed esophagogastric junction. Surg. Gynec. Obstet., 118, $1205 \sim 1216,1964$. 